\title{
Water use of cowpea under deficit irrigation and cultivation systems in semi-arid region
}

\author{
Rômulo M. O. de Freitas ${ }^{1}$, Jeferson L. D. Dombroski², Francisco C. L. de Freitas ${ }^{3}$, \\ Narjara W. Nogueira ${ }^{2}$, Tiago S. Leite ${ }^{4} \&$ Sidney C. Praxedes ${ }^{5}$ \\ ${ }^{1}$ Instituto Federal de Educação, Ciência e Tecnologia Baiano. Valença, BA, Brasil. E-mail: romulomagno_23@hotmail.com (Corresponding author) - \\ ORCID: 0000-0002-2422-0118 \\ ${ }^{2}$ Universidade Federal Rural do Semi-Árido/Centro de Ciências Agrárias/Departamento de Ciências Agronômicas e Florestais. Mossoró, RN, Brasil. \\ E-mail: jeferson@ufersa.edu.br - ORCID: 0000-0002-7888-1456; narjara.nogueira@ufersa.edu.br - ORCID: 0000-0002-6242-463X \\ ${ }^{3}$ Universidade Federal de Viçosa/Departamento de Fitotecnia. Viçosa, MG, Brasil. E-mail: fclaudiof@yahoo.com.br - ORCID: 0000-0003-1911-7201 \\ ${ }^{4}$ Universidade Federal Rural do Semi-Árido/Programa de Pós-Graduação em Fitotecnia. Mossoró, RN, Brasil. E-mail: tiagosousa@usp.br - ORCID: \\ 0000-0003-0398-4968 \\ ${ }^{5}$ Universidade Federal do Rio Grande do Norte/Escola Agrícola de Jundiaí. Macaíba, RN, Brasil. E-mail: sidneypraxedes@gmail.com - ORCID: 0000- \\ 0002-6456-2454
}

\begin{abstract}
The resilience of crops to drought depends heavily on the cultural practices adopted, which can have a direct effect on water use efficiency. The aim of this study was to assess the influence of irrigation intervals on the growth, water consumption and water use efficiency of cowpea crops (cv. BRS Guariba) under conventional and no-tillage systems. The experiment was carried out in the semi-arid region of Rio Grande do Norte, Brazil, using a split-plot in a randomised complete block design, with four replications. Treatments consisted of two cultivation systems in the whole plots (conventional and no-tillage) and six irrigation intervals in the subplots $(2,6,10,14,18$ and 22 days) which were applied at full bloom. The biomass of the different parts of the plant, leaf area and leaf area index were assessed at 64 days after sowing (DAS) and grain yield, water consumption and water use efficiency at 70 DAS. No-tillage is a promising cultivation technique for cowpea crops, promoting higher grain yield and water use efficiency under semi-arid conditions. This system allows cowpea cultivation with irrigation intervals of 10 or 14 days, with no or small reduction in yield, respectively.
\end{abstract}

Key words: Vigna unguiculata, no-tillage, mulch, water deficit

\section{Uso da água em feijão-caupi sob irrigação deficitária e sistemas de cultivo em região semiárida}

RESUMO: A resiliência das culturas à seca depende fortemente das práticas culturais adotadas, as quais podem ter um efeito direto sobre a eficiência de uso da água. O objetivo deste estudo foi avaliar a influência de turnos de rega sobre o crescimento, consumo de água e eficiência de uso da água do feijão-caupi (cv. BRS Guariba) nos sistemas de plantio direto e convencional. O experimento foi conduzido na região semiárida do Rio Grande do Norte, Brasil, utilizando-se blocos completos casualizados, no esquema de parcelas subdivididas, com quatro repetições. Nas parcelas, foram avaliados dois sistemas de plantio (convencional e direto) e, nas subparcelas, seis intervalos de irrigação $(2,6,10,14,18$ e 22 dias) que foram aplicados em pleno florescimento. Foram avaliados a biomassa das diferentes partes da planta, a área foliar e o índice de área foliar, aos 64 dias após a semeadura (DAS), além do rendimento de grãos, consumo de água e eficiência de uso da água, aos 70 DAS. O plantio direto é uma técnica de cultivo promissora para a cultura do feijãocaupi, promovendo maior rendimento de grãos e eficiência de uso da água sob condições semiáridas. Este sistema permite o cultivo de feijão-caupi com turnos de rega de 10 ou 14 dias, com nenhuma ou pequena redução na produtividade, respectivamente.

Palavras-chave: Vigna unguiculata, plantio direto, cobertura morta, déficit hídrico 


\section{INTRODUCTION}

Cowpea [Vigna unguiculata (L.) Walp.] has good capacity to withstand drought, by restraining its own growth, especially in the vegetative stage, and resuming it with the return of rainfall, allowing recovery of plant mass in a very effective way (Hall, 2012).

Grain yield of cowpea in the northeast region of Brazil is relatively low due to the low-cost technologies applied, with values ranging from 300 to $400 \mathrm{~kg} \mathrm{ha}^{-1}$ (Soares et al., 2006; Freire Filho et al., 2011). On the other hand, in the central region, which has a higher level of technology and favourable environmental conditions, the average yield is $960 \mathrm{~kg} \mathrm{ha}^{-1}$ (Freire Filho et al., 2011).

The resilience of crops to drought depends heavily on the cultural practices adopted. Soil management practices have a direct influence on crop yield and are determinants of economically viable production (Souza et al., 2014). Among these practices, there are the conventional and no-tillage systems. Although the former is the most commonly used soil management practice, the no-tillage system results in better water infiltration and conservation. In addition, the surface organic matter in no-tillage systems helps to prevent extreme temperature fluctuations in the soil, acting as insulation (Bizari et al., 2009; Coelho et al., 2013a). In view of these characteristics, when compared to the conventional system, no-tillage can promote higher yield under deficit irrigation (Souza et al., 2016).

Measurement of water use efficiency indicators is a good way to evaluate crop response to water availability as it relates biomass (or commercial) production with the water applied or used by plants (Liu \& Stützel, 2004; Puppala et al., 2005). Notillage has been reported to lead to higher water use efficiency in melon (Teófilo et al., 2012), bell pepper (Coelho et al., 2013c) and kidney beans (Bizari et al., 2009). Therefore, the aim of this study was to assess the effect of irrigation intervals on the growth, water consumption and water use efficiency of cowpea crop under conventional and no-tillage systems in a semi-arid region.

\section{Material ANd Methods}

The experiment was carried out in the Department of Plant Science of the Universidade Federal Rural do Semi-Árido in Mossoró, Rio Grande do Norte, Brazil, under semi-arid conditions, with coordinates $5^{\circ} 11^{\prime} \mathrm{S}, 37^{\circ} 20^{\prime} \mathrm{W}$ and altitude of $18 \mathrm{~m}$. Temperature data were collected from a nearby meteorological station. During the experiment, the average temperature recorded was $27.9^{\circ} \mathrm{C}$, with a daily maximum of $33.5^{\circ} \mathrm{C}$ and daily minimum of $23.6^{\circ} \mathrm{C}$. As for the relative humidity of the air, the average value was $60.9 \%$, with a daily maximum of $79.1 \%$ and a daily minimum of $35.5 \%$. In this period, there was only $5 \mathrm{~mm}$ of rainfall at 31 days after sowing (DAS).

A split-plot in a randomised complete block design with four replications was used. Treatments consisted of two cultivation systems in the whole plots (conventional and notillage) and six irrigation intervals in the subplots $(2,6,10$,
14,18 and 22 days). The suspension of irrigation started at full bloom (70\% of the plants with at least one flower) which occurred at 34 DAS. The experimental unit consisted of four rows of $5 \mathrm{~m}$ in length and spaced $0.5 \mathrm{~m}$ apart, but samples were collected only from the inner two rows. There was $1.0 \mathrm{~m}$ distance between plots to ensure the isolation of treatments.

In the area under no-tillage, the mulch was obtained by planting Urochloa brizantha (A.Rich.) R.D.Webster. cv. Marandu in the previous rainy season. The plants were desiccated 30 days before the experiment using $1.9 \mathrm{~kg} \mathrm{ha}^{-1}$ of the herbicide glyphosate. As for the area under conventional cultivation, the soil was prepared by one ploughing and two harrowing passes. These areas had been cultivated under notillage and conventional systems, respectively, for the previous four years.

Fertilization was performed based on a composite soil sample $(0-20 \mathrm{~cm}$ depth). A drip irrigation system was installed, with $1.7 \mathrm{~L} \mathrm{~h}^{-1}$ emitters spaced $0.3 \mathrm{~m}$ apart. To avoid differences in water levels between treatments, daily readings were collected from tensiometers placed at a depth of $20 \mathrm{~cm}$. The amount of water supplied to the treatments was calculated based on the volume applied to each replicate, taking into account the flow rate and irrigation time. The rainfall observed during the experiment was added to this value. Control plants (no water deficit) were irrigated every two days in order to maintain soil moisture at $70 \%$ field capacity (Teixeira et al., 2010).

The cowpea cultivar used was the semi-erect BRS Guariba, commonly grown for grain production. Sowing and fertilization were performed using a hand planter, adjusted to deliver 2-4 seeds per hole and $250 \mathrm{~kg} \mathrm{ha}^{-1}$ of NPK 6-24-12. The spacing between plants in a row was $0.3 \mathrm{~m}$ and, after emergence, these were thinned to two per hole. For the conventional system, weeds were controlled by hoeing at 15 and 30 DAS. In the notillage system, weeds were trimmed where necessary at 25 DAS.

At 64 DAS, one plant per replicate was collected. Each plant was divided into different parts and placed in a forced-air drying oven at $65^{\circ} \mathrm{C}$ for assessment of stem, inflorescence, leaf, pod and total plant dry weight, leaf area and leaf area index (Benincasa, 2003). The remaining plants were harvested at 70 DAS in order to determine grain yield $\left(\mathrm{kg} \mathrm{ha}^{-1}\right)$ at $13 \%$ relative humidity (Cardoso \& Ribeiro, 2006). The water use efficiency $\left(\mathrm{kg} \mathrm{m}^{-3}\right)$ was calculated based on the grain yield and water consumption data.

Data were subjected to analysis of variance by the F-test at the 0.05 level using the Sisvar statistical analysis system (Ferreira, 2011). When significant, means were compared by the Tukey test at the 0.05 level. The dependent data were analysed by regression analysis using the SigmaPlot software (version 11.0; Systat Software, Inc.).

\section{Results AND Discussion}

Statistically significant differences were observed for all variables assessed, both in cultivation systems and irrigation intervals. There was also a significant interaction between these factors for most variables, except for pod and total plant dry weight. 
For the control treatment (two days without irrigation), the leaf area (Figure 1A) and leaf area index (Figure 1B) of plants under no-tillage were approximately $19 \%$ higher than with the conventional system. Urchei et al. (2000) also found that no-tillage increased the leaf area of common bean, attributing this effect to greater leaf expansion and lower abscission. There was an interesting response of leaf area and leaf area index to irrigation intervals under no-tillage. As can be observed in Figure 1, for no-tillage system these variables hardly changed during the period up to 14 days without irrigation, decreasing sharply thereafter (by approximately 50\%). Moreover, they only reached the levels recorded in the conventional system at an irrigation interval of 22 days, which demonstrates that prolonged water deficit affects plants from both cultivation systems equally. Conversely, in the conventional system, the reductions in leaf area and leaf area index showed a linear response. These results are probably related to higher water availability in the no-tillage system, as verified for cowpea by Bastos et al. (2012).

Compared with the conventional system, no-tillage also increased the stem, inflorescence, leaf and pod dry weight (Figures 2A, B, C and D, respectively). Deficit irrigation in

$$
\begin{array}{ll}
\longrightarrow & \mathrm{Y}(\mathrm{CS})=9705.6339-221.2386 \mathrm{x} \mathrm{R}^{2}=0.98 \\
---\bigcirc & \mathrm{Y}(\mathrm{NS})=10989.16 /(1+\exp (-(\mathrm{x}-21.8180) /-2.581)) \mathrm{R}^{2}=0.97
\end{array}
$$

A.

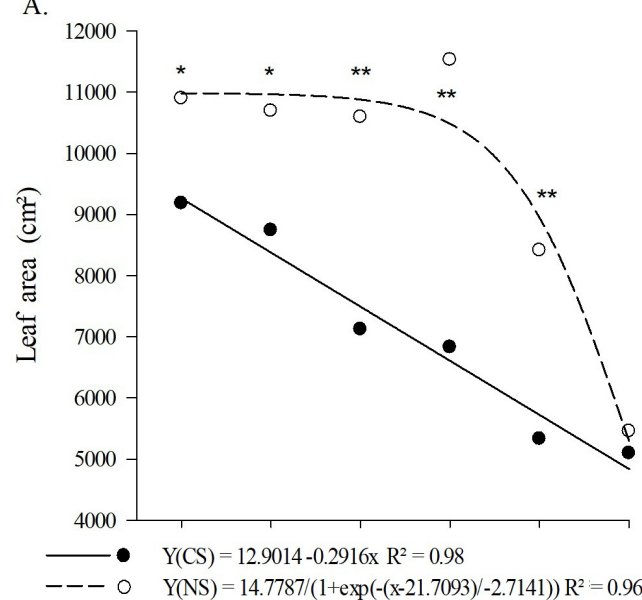

$$
\text { B. }
$$

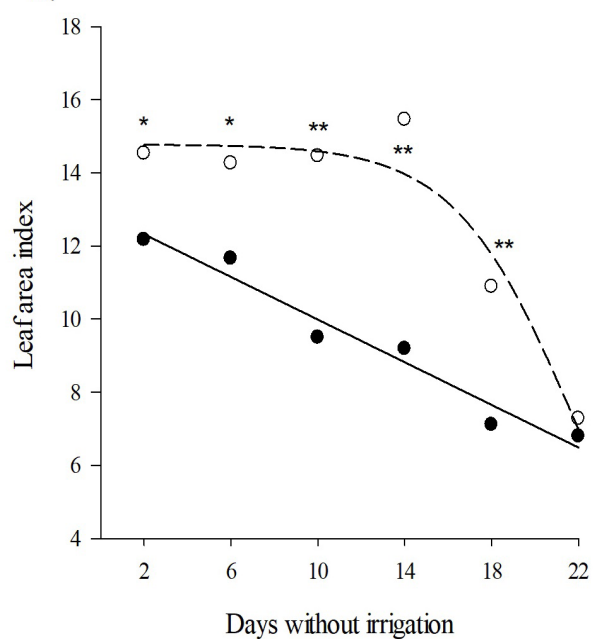

Days without irrigation

The symbols represent the means of four replicates, whereas ${ }^{*}$ and ${ }^{* *}$ indicate significance at the 0.05 and 0.01 probability level, respectively, by the F-test

Figure 1. Leaf area (A) and leaf area index (B) of cowpea as affected by irrigation intervals and conventional (CS) and notillage (NS) systems in a semi-arid region

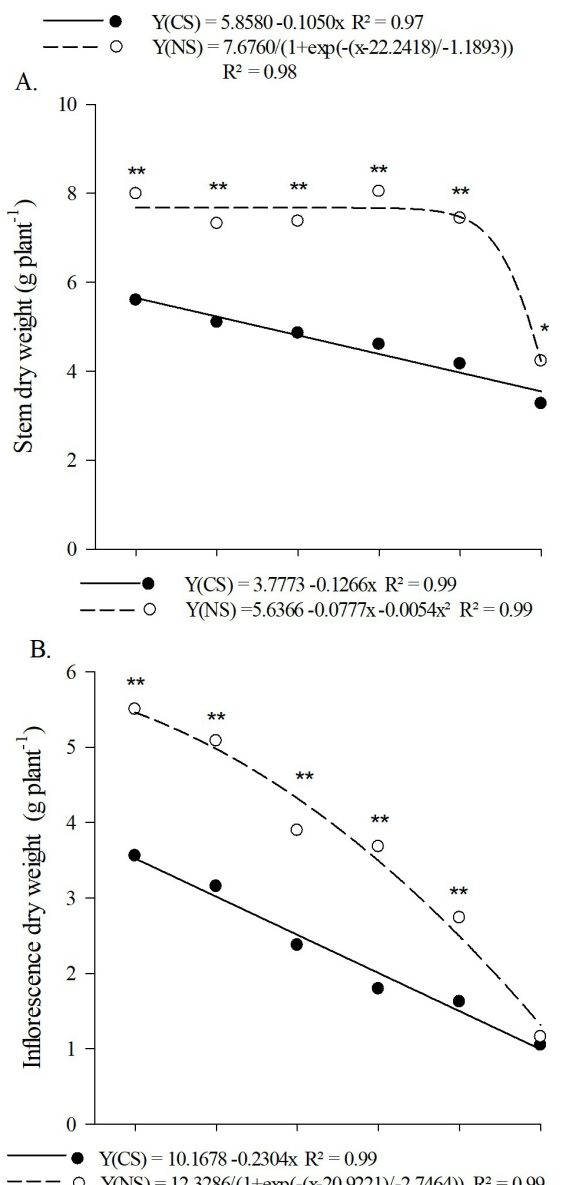

C.
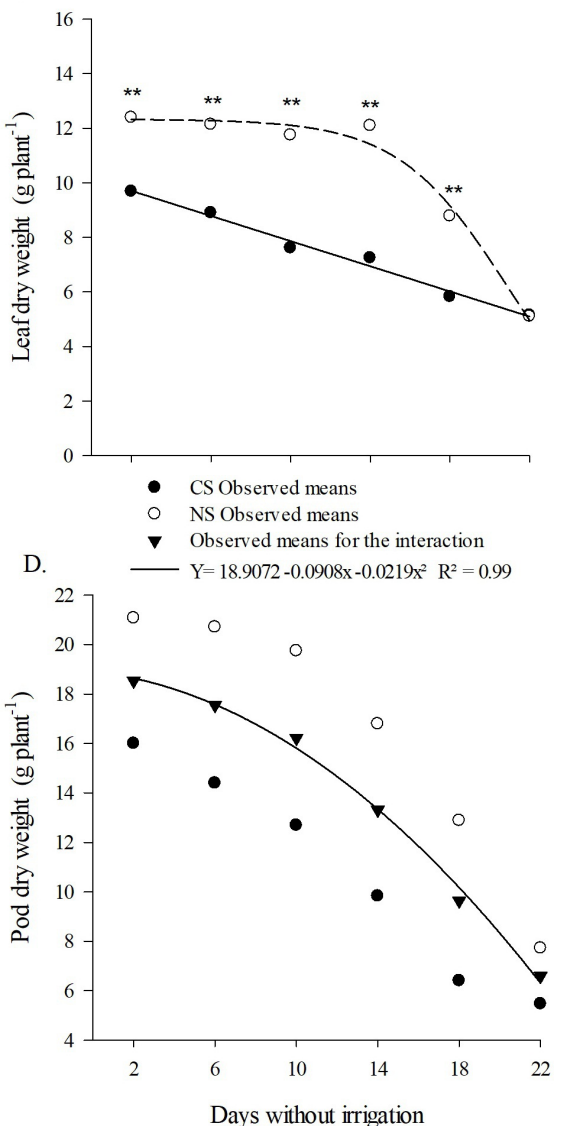

The symbols represent the means of four replicates, whereas ${ }^{*}$ and ${ }^{* *}$ indicate significance at the 0.05 and 0.01 probability level, respectively, by the F-test

Figure 2. Stem (A), inflorescence (B), leaf (C) and pod (D) dry weight of cowpea as affected by irrigation intervals and conventional (CS) and no-tillage (NS) systems in a semi-arid region 
the former system caused a linear decrease in most of these variables. However, similar to that observed for leaf area and leaf area index, stem and leaf dry weight under no-tillage remained essentially the same up to 18 and 14 days without irrigation, respectively. Inflorescence dry weight under notillage showed a different pattern. A possible explanation for this difference is in the experimental design, given that the irrigation intervals started at full bloom, which could have prevented posterior flower formation. Compared to other parts of the plant, the floral structures of cowpea proved to be highly sensitive to water deficit, even under no-tillage.

In both cultivation systems, the pod (Figure 2D) and total plant dry weight (Figure 3A) showed a quadratic response to the irrigation intervals. The similarity between the curves of these two variables can be explained by the contribution of pods to the total plant biomass, as the former corresponded to about $40 \%$ of the latter. Linhares et al. (2014) found that pods were the main contributor to the total dry weight of this cowpea cultivar, i.e., the effect of water deficit on pod dry weight directly influenced the total plant dry weight. An irrigation interval of 22 days reduced pod dry weight by about $66 \%$ compared with control plants. Oliveira et al. (2011) observed only a $27 \%$ decrease in this variable under low water availability. However, Leite \& Virgens Filho (2004) reported that pod dry weight was reduced by $61 \%$ when there was water deficit at the flowering stage.

For all irrigation intervals, grain yield was clearly higher under no-tillage than with the conventional system (Figure 3B), with a difference of almost $519 \mathrm{~kg} \mathrm{ha}^{-1}$ between control plants. This corresponds to approximately $31 \%$ of the grain yield of plants irrigated every two days in the conventional system $\left(1694 \mathrm{~kg} \mathrm{ha}^{-1}\right)$. Similar results were observed by Bizari et al. (2009), who reported a $36 \%$ increase in the grain yield of common bean grown under no-tillage.

The highest water consumption values were recorded under conventional cultivation (Figure 3C). For the conventional and no-tillage systems, the total irrigation depths were 366 and $310 \mathrm{~mm}$, respectively. The former value is similar to that reported by Bastos et al. (2012) for the same cowpea cultivar. The reduction in water consumption under no-tillage is a well-known phenomenon, reaching up to $29 \%$ for common bean (Pereira et al., 2002), 10\% for tomato (Marouelli et al., 2006) and 13\% for cabbage (Marouelli et al., 2010) and melon (Teófilo et al., 2012).

Regarding water use efficiency, which is expressed as the grain yield per unit of water consumed, no-tillage also yielded better results than the conventional system. The water use efficiency of the control plants under no-tillage was $51 \%$ higher than with the conventional system (Figure 3D). Bizari et al. (2009) observed a $45 \%$ increase in the water use efficiency of common bean under no-tillage. The authors explain that this may be associated with lower soil water evaporation. This is because the mulch forms a physical barrier that prevents the direct incidence of solar radiation and reduces soil exposure to wind, therefore, controlling soil temperature and the water evaporation rate, particularly during the hottest hours of the day (Coelho et al., 2013b). According to Allen et al. (2006),
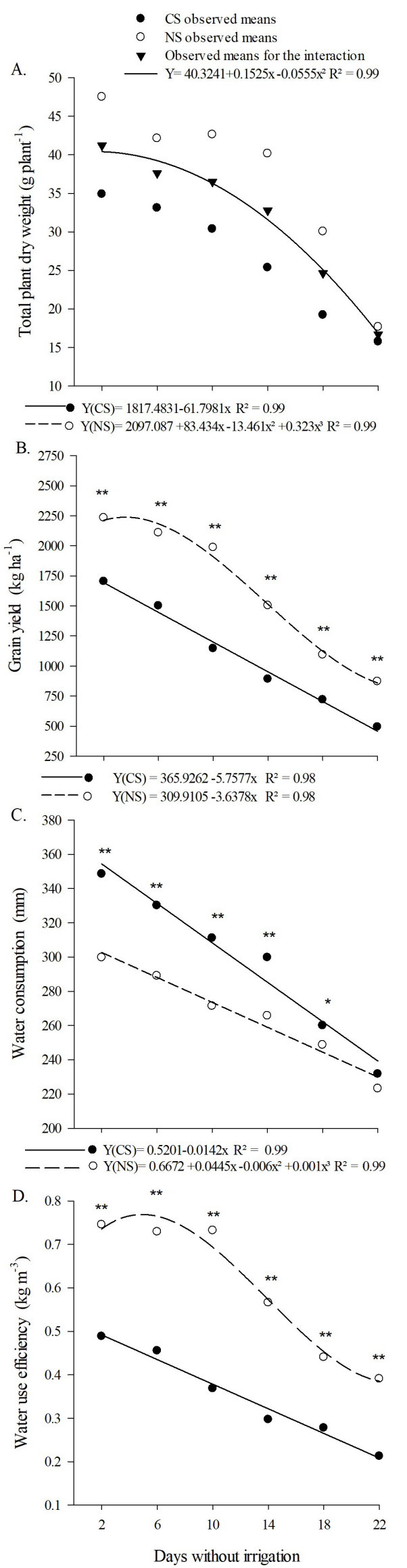

The symbols represent the means of four replicates, whereas * and ${ }^{* *}$ indicate significance at the 0.05 and 0.01 probability level, respectively, by the F-test

Figure 3. Total plant dry weight (A), grain yield (B), water consumption (C) and water use efficiency (D) of cowpea as affected by irrigation intervals and conventional (CS) and no-tillage (NS) systems in a semi-arid region 
solar radiation, air temperature, wind speed and relative humidity are the most important climatic parameters to consider when evaluating soil water evaporation.

The responses of grain yield and water use efficiency to the irrigation intervals under no-tillage differed from those observed for the other variables discussed so far. In the conventional system, there was a linear decrease in grain yield and water use efficiency with increasing number of days without irrigation. In contrast, under no-tillage, these variables showed a sigmoidal pattern, with little decrease up to 10 days without irrigation and falling rather abruptly after this. These results indicate that no-tillage attenuates the effect of water deficit on plants, as reported for common bean by Pavani et al. (2008). With the longest irrigation interval (22 days), grain yield decreased by 72 and $61 \%$ compared with the control in the conventional and no-tillage systems, respectively, and water use efficiency was considerably higher under no-tillage.

The present results showed that cowpea crops grown under no-tillage had lower water consumption and higher biomass accumulation, grain yield and water use efficiency when compared with the conventional system. Therefore, this cultivation technique is highly promising, particularly for use in semi-arid regions, where droughts are common and water is a scarce and expensive commodity.

\section{Conclusions}

1. Deficit irrigation negatively affects the biomass accumulation, grain yield and water use efficiency of cowpea crop under semi-arid conditions, in different ways, and these effects are attenuated by growing plants under no-tillage.

2. No-tillage is a promising cultivation technique for cowpea crop under semi-arid conditions, promoting higher grain yield and lower water consumption than the conventional system.

3. No-tillage allows cowpea cultivation with irrigation intervals of 10 or 14 days, with no or small reduction in yield, respectively.

\section{Literature Cited}

Allen, R. G.; Pereira, L. S.; Raes, D.; Smith, M. Evapotranspiración del cultivo: Guías para la determinación de los requerimientos de agua de los cultivos. 1.ed. Rome: FAO, 2006. 322p.

Bastos, E. A.; Ramos, H. M. M.; Andrade Júnior, A. S. de; Nascimento, F. N. do; Cardoso, M. J. Parâmetros fisiológicos e produtividade de grãos verdes do feijão-caupi sob déficit hídrico. Water Resources and Irrigation Management, v.1, p.31-37, 2012.

Benincasa, M. P. Análise de crescimento de plantas: Noções básicas. 2.ed. Jaboticabal: FUNEP, 2003. 41p.

Bizari, D. R.; Matsura, E. E.; Roque, M. W.; Souza, A. L. de. Consumo de água e produção de grãos do feijoeiro irrigado em sistemas plantio direto e convencional. Ciência Rural, v.39, p.2073-2079, 2009. https://doi.org/10.1590/S0103-84782009000700018

Cardoso, M. J.; Ribeiro, V. Q. Desempenho agronômico do feijãocaupi, cv. Rouxinol, em função de espaçamentos entre linhas e densidades de plantas sob regime de sequeiro. Revista Ciência Agronômica, v.37, p.102-105, 2006.
Coelho, M. E. H.; Freitas, F. C. L. de; Cunha, J. L. X. L.; Dombroski, J. L. D.; Santana, F. A. O. de. Interferência de plantas daninhas no crescimento do pimentão nos sistemas de plantio direto e convencional. Revista Caatinga, v.26, p.19-30, 2013 a.

Coelho, M. E. H.; Freitas, F. C. L. de; Cunha, J. L. X. L.; Medeiros. J. F. de; Silva, M. G. O. da. Production and efficiency of water usage in capsicum crops under no-tillage and conventional planting systems. Revista Ciência Agronômica, v.44, p.741-749, 2013 b. https://doi.org/10.1590/S1806-66902013000400010

Coelho, M. E. H.; Freitas, F. C. L. de; Cunha, J. L. X. L.; Silva, K. S.; Grangeiro, L. C.; Oliveira, J. B. Coberturas do solo sobre a amplitude térmica e a produtividade de pimentão. Planta Daninha, v.31, p.369-378, 2013c. https://doi.org/10.1590/S010083582013000200014

Ferreira, D. F. Sisvar: A computer statistical analysis system. Ciência e Agrotecnologia, v.35, p.1039-1042, 2011. https://doi.org/10.1590/ S1413-70542011000600001

Freire Filho, F. R.; Ribeiro, V. Q.; Rocha, M. de M.; Silva, K. J. D. e; Nogueira, M. do S. da R.; Rodrigues, E. V. Feijão-caupi no Brasil: Produção, melhoramento genético, avanços e desafios. 1.ed. Teresina: Embrapa Meio-Norte, 2011. 84p.

Hall, A. E. Phenotyping cowpeas for adaptation to drought. Frontiers in Physiology, v.3, p.1-8, 2012. https://doi.org/10.3389/ fphys.2012.00155

Leite, M. de L.; Virgens Filho, J. S. das. Produção de matéria seca em plantas de caupi [Vigna unguiculata (L.) Walp] submetidas a déficits hídricos. Publication UEPG: Ciências Exatas e da Terra, Agrárias e Engenharias, v.10, p.43-51, 2004.

Linhares, C. M. de S.; Freitas, F. C. L. de; Silva, K. de S.; Lima, M. F. P. de; Dombroski, J. L. D. Crescimento do feijão-caupi sob efeito dos herbicidas fomesafen e bentazon+imazamox. Revista Caatinga, v.27, p.41-49, 2014.

Liu, F.; Stützel, H. Biomass partitioning, specific leaf area, and water use efficiency of vegetable amaranth (Amaranthus spp.) in response to drought stress. Scientia Horticulturae, v.102, p.15-27, 2004. https://doi.org/10.1016/j.scienta.2003.11.014

Marouelli, W. A.; Abdalla, R. P.; Madeira, N. R.; Oliveira, A. S. de; Souza, R. F. de. Eficiência de uso da água e produção de repolho sobre diferentes quantidades de palhada em plantio direto. Pesquisa Agropecuária Brasileira, v.45, p.369-375, 2010. https:// doi.org/10.1590/S0100-204X2010000400004

Marouelli, W. A.; Silva, H. R. da; Madeira, N. R. Uso de água e produção de tomateiro para processamento em sistema de plantio direto com palhada. Pesquisa Agropecuária Brasileira, v.41, p.1399-1404, 2006. https://doi.org/10.1590/S0100-204X2006000900008

Oliveira, G. A.; Araújo, W. F.; Cruz, P. L. S.; Lima, W. L. M. da; Ferreira, G. B. Resposta do feijão-caupi as lâminas de irrigação e as doses de fósforo no cerrado de Roraima. Revista Ciência Agronômica, v.42, p.872-882, 2011. https://doi.org/10.1590/ S1806-66902011000400008

Pavani, L. C.; Lopes, A. S.; Galbeiro, R. B. Manejo da irrigação na cultura do feijoeiro em sistemas plantio direto e convencional. Engenharia Agrícola, v.28, p.12-21, 2008. https://doi.org/10.1590/ S0100-69162008000100002

Pereira, A. L.; Moreira, J. A. A.; Klar, A. E. Efeito de níveis de cobertura do solo sobre o manejo da irrigação do feijoeiro (Phaseolus vulgaris L.). Irriga, v.7, p.42-52, 2002. https://doi.org/10.15809/ irriga.2002v7n1p42 
Puppala, N.; Fowler, J. L.; Jones, T. L.; Gutschick, V.; Murray, L. Evapotranspiration, yield, and water-use efficiency responses of Lesquerella fendleri at different growth stages. Industrial Crops and Products, v.21, p.33-47, 2005. https://doi.org/10.1016/j. indcrop.2003.12.005

Soares, A. L. de L.; Ferreira, P. A. A.; Pereira, J. P. A. R.; Vale, H. M. M. do; Lima, A. S.; Andrade, M. J. B. de; Moreira, F. M. de S. Eficiência agronômica de rizóbios selecionados e diversidade de populações nativas nodulíferas em Perdões (MG): II - Feijoeiro. Revista Brasileira de Ciência do Solo, v.30, p.803-811, 2006. https://doi.org/10.1590/S0100-06832006000500006

Souza, H. A. de; Cavalcante, A. C. R.; Tonucci, R. G.; Pompeu, R. C. F. F.; Souza, M. C. M. R. de; Maia, C. E. Níveis críticos para atributos do solo pela distribuição normal reduzida em culturas anuais de subsistência. Revista Brasileira de Engenharia Agrícola e Ambiental, v.18, p.425-430, 2014. https://doi.org/10.1590/S141543662014000400010
Souza, T. M. A. de; Souto, L. S.; Dutra Filho, J. de A.; Sá, F. V. da S.; Oliveira Neto, H. T. de; Paiva, E. P. de; Souza, A. dos S. Cowpea growth and production under different levels of available water and soil cover. International Journal of Current Research, v.8, p.39122-39126, 2016.

Teixeira, I. R.; Silva, G. C. da; Oliveira, J. P. R. de; Silva, A. G. da; Pelá, A. Desempenho agronômico e qualidade de sementes de cultivares de feijão-caupi na região do cerrado. Revista Ciência Agronômica, v.41, p.300-307, 2010. https://doi.org/10.1590/S1806-66902010000200019 Teófilo, T. M. S.; Freitas, F. C. L.; Medeiros, J. F.; Fernandes, D.; Grangeiro, L. C.; Tomaz, H. V. Q.; Rodrigues, A. P. M. S. Eficiência no uso da água e interferência de plantas daninhas no meloeiro cultivado nos sistemas de plantio direto e convencional. Planta Daninha, v.30, p.547-556, 2012. https://doi.org/10.1590/S0100-83582012000300010

Urchei, M. A.; Rodrigues, J. D.; Stone, L. F. Análise de crescimento de duas cultivares de feijoeiro sob irrigação, em plantio direto e preparo convencional. Pesquisa Agropecuária Brasileira, v.35, p.497-506, 2000. https://doi.org/10.1590/S0100-204X2000000300004 